\title{
Allogeneic hematopoietic stem cell transplantation: transfusion issues
}

This article was published in the following Dove Press journal:

International Journal of Clinical Transfusion Medicine

5 May 2016

Number of times this article has been viewed

\author{
Çiğdem Akalın Akkök ${ }^{1,2}$ \\ 'Department of Immunology and \\ Transfusion Medicine, Oslo University \\ Hospital, Ullevaal, Oslo, Norway; \\ ${ }^{2}$ Department of Clinical Immunology \\ and Transfusion Medicine, Lund \\ University Hospital, Lund, Sweden
}

Abstract: Allogeneic hematopoietic stem cell transplantation (AHSCT) is an intention-to-cure treatment strategy in several malignancies and nonmalignancies. The number of patients receiving AHSCT is increasing due to new indications, and more elderly patients with comorbidities are included in the protocols. Survival of the patients undergoing AHSCT has improved owing to better patient care, including optimization of transfusion support, which has a major contribution. However, transfusion can also be hazardous. Increasing awareness about transfusion and finding the balance between avoiding unnecessary transfusions and transfusing the correct component when needed are the key issues. Myeloablative conditioning results in pancytopenia, and the patients are prone to infections, anemia, and bleeding both before and after transplantation. Until red cell and platelet engraftment, the patients are usually transfusion dependent needing red cell and/or platelet components. Physicians dealing with AHSCT patients should be well informed about the attributes of the blood components they order. Knowledge about transfusion indications, triggers, and how to prevent and manage eventual transfusion complications is also required. The clinical picture can be challenging, and transplantation/treatment-related toxicity/complications can sometimes be difficult to distinguish from a transfusion complication, especially if the latter one took place, for instance, several days or weeks ago. ABO compatibility between the patient and the donor is not a prerequisite when choosing human leukocyte antigen-matched hematopoietic stem cell donor. Consequently, ABO incompatibility exists in $\sim 40 \%$ of the cases and brings some immunohematological issues. ABO incompatibility is defined as major, minor, and bidirectional according to the direction of blood group antibodies to blood group antigens in patients and donors. ABO incompatibility necessitates blood components that are compatible with both the patient and the donor.

Keywords: hematopoietic stem cell transplantation, transfusion, red cell transfusion, platelet transfusion

\section{Introduction}

Transfusion support has made it possible to give patients a treatment that otherwise would have been fatal. Allogeneic hematopoietic stem cell transplantation (AHSCT) is an intention-to-cure treatment strategy in several malignancies and nonmalignancies. Due to pre-transplantation myeloablative conditioning that results in iatrogenic pancytopenia, the patient is prone to infections, anemia, and bleeding. Until transplanted hematopoietic stem cells (HSCs) start producing blood cells, many patients need replacement therapy with transfusions. The objective of this review is to provide brief information about transfusion issues in AHSCT mainly for the hematologists working in this field. Other types of cell transplantations will not be
Correspondence: Çiğdem Akalın Akkök Department of Immunology and Transfusion Medicine, Oslo University Hospital, Kirkeveien 166, 0407 Oslo, Norway

Tel +47 2 21। 8887

Email cigdemakak@yahoo.no
International Journal of Clinical Transfusion Medicine 2016:4 29-42

Dovepress

http://dx.doi.org/1 0.2/47/IJCTM.S73073 (c) (1) (5) 2016 Akkök. This work is published and licensed by Dove Medical Press limited. The full terms of this license are available at https://www.dovepress.com/terms.php and (c) hereby accept the Terms. Non-commercial uses of the work are permitted without any further permission from Dove Medical Press Limited, provided the work is properly attributed. For permission for commercial use of this work, please see paragraphs 4.2 and 5 of our Terms (https://www.dovepress.com/terms.php 
addressed. Transfusions are only a part of all supportive therapies, including antibiotics and prevention and treatment of graft-versus-host disease (GvHD). In the past decade, there has been substantial improvement in patient outcomes such as increased long-term survival and reduction in major complications following AHSCT. ${ }^{1}$ Increased quality of blood components may have had contributions to this improvement. Transfusion itself is a form of allogeneic transplantation as viable blood cells of a donor are given to a recipient whose immunological system is different from that of the blood donor. Although immunosuppression is a prerequisite in AHSCTs, transfusions are given to not always immunosuppressed patients and immunosuppression would not avoid the majority of transfusion complications anyway. Transfusion complications must preferably be prevented, monitored, and when unpreventable optimally treated. Revealing a transfusion complication will enable the physician in charge to give the proper treatment. There should always be correct and well-founded indications for transfusing patients with any blood component. There are certain obvious indications for transfusion in the AHSCT setting. However, unnecessary transfusions should definitely be avoided (Table 1). In a critically ill patient, even "mild" transfusion complications may jeopardize the clinical situation and may be fatal. Therefore, it is essential to have the proper understanding, knowledge, and awareness about transfusion issues in patients going through AHSCTs.

Although some of these issues, such as transfusion complications, apply also for other patient groups, they will be reviewed in this article for the sake of completeness and also because differential diagnosis may have a decisive impact on outcome in AHSCT patients. Transfusion indications, thresholds, doses, and complications mainly for red cell concentrates (RCC) and platelet concentrates (PC) will be addressed with emphasis on AHSCT. Special procedures such as leukoreduction and irradiation are important to prevent transfusion complications. ABO blood group incompatibilities between the patient and the donor in both transfusion and transplantation settings, including transfusion recommendations, will be finally discussed.

\section{Transfusion requirements according to sources of HSCs}

Sources of HSCs are bone marrow (BM), peripheral blood (PB), and umbilical cord blood. Transfusion support is mainly the same regardless of the HSC source. However, transfusion requirements may continue for a longer period of time when BM-HSCs are used. This is because of longer time to hematopoietic engraftment with BM-HSCs. ${ }^{2}$ On the other hand, less platelet transfusions will be necessary due to rapid platelet engraftment when sufficient number of CD34+ PB-HSC is transplanted. Despite this difference in adults with hematological malignancies, overall survival of the patients is similar, irrespective of whether they have received $\mathrm{PB}-\mathrm{HSC}$ or BM-HSC. ${ }^{2}$

\section{Blood components}

In AHSCT patients, RCCs and PCs are the most utilized blood components, while plasma being a component used to a lesser extent, and granulocyte transfusions are not routinely used as they are not an established treatment option. ${ }^{3,4}$ While RCC, PC, and plasma are usually "shelf products" (unless the patient is immunized), granulocyte concentrates must be prepared on demand to overcome life-threatening bacterial or fungal infections when antibiotics and granulocyte colony-stimulating factor do not provide the clinical effect. However, due to a recent Cochrane review there was lowgrade evidence that prophylactic granulocyte transfusions decrease the risk of bacteremia or fungemia. There was not sufficient evidence to determine whether prophylactic granulocyte transfusions may reduce the risk of mortality from infection and overall mortality. ${ }^{4}$ It should also be kept in mind that premedication with steroids and granulocyte colony-stimulating factor prior to granulocyte harvesting is a significant burden for the granulocyte donor.

\section{Red cell concentrates}

Patients undergoing AHSCT need life-saving red cell transfusions; a mean of $6.2 \pm 8.6$ (range: 0-76) units were reported to be transfused within 100 days of transplantation. Female sex, unrelated donor transplant, leukemia, high-intensity conditioning regimen, total body irradiation, and infections were associated with higher transfusion requirements. ${ }^{6,7}$ Zhang et al showed that red cell transfusions were more effective before AHSCT (from day -60 to day 0) compared to during (from day 0 to day 52) AHSCT and when the donor and the patient had the same ABO type. ${ }^{7}$ These authors define effectiveness as hemoglobin elevation by $1 \mathrm{~g} 24$ hours after transfusion of two units. ${ }^{7}$ Increased number of transfusions is a risk for poorer outcome. ${ }^{8}$

The role of erythropoietin in AHSCT has been controversial due to the lack of guidelines; some studies show no reduced red cell transfusion needs when erythropoietin is used, ${ }^{9}$ and some others do not exclude some beneficial effect. ${ }^{10,11}$ Patients with low hemoglobin before AHSCT need more red cell transfusions. ${ }^{12}$ 
The etiology of the low hemoglobin level should be investigated and targeted treatment should be chosen. Iron deficiency needs to be treated by iron supplements. Whether the patient has symptoms and how severe these are depends usually on the fact if anemia has occurred acutely or not. Chronic anemia is mostly tolerated better. Pure red cell anemia (PRCA) is a complication seen after major ABO-mismatched AHSCT. Delayed engraftment of erythropoiesis in PRCA leads to prolonged red cell transfusion dependency. ${ }^{13}$

\section{Indications and threshold for red cell transfusions}

Disease- and/or treatment-related symptom-giving anemia and nonsurgical bleeding in AHSCT patients are corrected by red cell transfusions until red cell engraftment occurs. How acute the hemoglobin fall is together with whether the fall is still going on should be a part of the decision to transfuse or not. Red cell transfusions are given in order to increase tissue oxygenation by increasing the hemoglobin concentration. Several guidelines based on studies investigating surgical or intensive care unit patients recommend restrictive transfusion strategy by transfusion threshold at a hemoglobin level of 6-7 $\mathrm{g} / \mathrm{dL}$ in a circulatory stable patient. ${ }^{14,15}$ However, transfusion thresholds for AHSCT patients are not established. Consequently, recommendations for other patient groups are adapted. The general tendency for most patient groups has been restrictive transfusion strategy, unless the patient has coronary heart disease. Because AHSCT is extended to include elderly patients with comorbidities such as cardiovascular diseases, higher transfusion thresholds for this group should be considered. The main outcome of restrictive transfusion strategy is better survival.

A survey of transfusion practices in pediatric patients undergoing AHSCT revealed that $60 \%$ of the institutions use $8 \mathrm{~g} / \mathrm{dL}$, while $25 \%$ use $7 \mathrm{~g} / \mathrm{dL}$ as the threshold. ${ }^{16}$ The threshold of $7 \mathrm{~g} / \mathrm{dL}$ caused significant reduction in the number of transfused units (from four to three) without negative impact on clinical outcomes. ${ }^{17}$

There is generally no indication for transfusion if the hemoglobin level is $>10 \mathrm{~g} / \mathrm{dL}$. Transfusing two units at the same time is seldom necesarry, ${ }^{18}$ unless there is ongoing bleeding or if the hemoglobin level is critically low and anemia is obviously symptomatic. A reassessment after each transfusion should be the standard. However, the patients should not suffer because of undertransfusion, either. It is therefore important to evaluate the whole patient, and not just the hemoglobin value. Prospective studies are needed and should be planned to establish the role of red cell transfusions in clinical outcomes of AHSCT. ${ }^{19}$

\section{Requirements of phenotype match when choosing RCCs}

In addition to $\mathrm{ABO}$ and $\mathrm{D}$ identical or compatible RCCs for all patients, in Norway, we also choose K-antigen-negative units for the K-negative female patients younger than 50 years old. ${ }^{20}$ While this is also the common practice in the rest of Europe, it is not the case in the USA. ${ }^{21} \mathrm{~K}$ immunization due to transfusion of K-positive blood components may cause severe hemolytic disease in the fetus and newborn in a subsequent pregnancy and therefore should be prevented. Additional phenotype match is not a prerequisite. Some AHSCT patients will be transfusion dependent for a long time. Despite many transfusions, some patients do not make antibodies, ie, they are not the so-called responders, while others who become alloimmunized against one blood group antigen may make several more antibodies in time with continuing transfusions. These responders will need antigen-negative RCCs when the antibody(ies) has clinical significance, meaning that antibody(ies) may cause hemolysis unless the transfused RCCs are antigen negative. Alloimmunization is discussed in detail in the "Transfusion complications" section.

\section{Platelet concentrates}

Treatment-induced thrombocytopenia and thrombocytopenia due to BM suppression because of the main disease and infections and/or sepsis are frequent issues in AHSCT patients; therefore it is thoroughly reviewed in this article. PCs are stored at $22^{\circ} \mathrm{C} \pm 2{ }^{\circ} \mathrm{C}$, which may provide a favorable condition for bacterial growth in a contaminated unit. Bacterial surveillance is recommended for each platelet component. ${ }^{22}$ A contaminated PC may already be transfused when a positive result is notified. The blood bank will then inform the clinical ward and advise special monitoring of the patient for an eventual septicemia. Regarding the blood bank inventory, PCs stored for a longer time are usually issued first. These PCs, either apheresis PCs (APCs) or buffy coat PCs (BCPCs), give decreased corrected count increment (CCI) and shorter transfusion intervals for patients with hematological malignancies. ${ }^{23}$ However, this CCI reduction is within acceptable limits.

\section{ABO-mismatched PCs}

Although many blood banks intend to provide ABO-identical $\mathrm{PCs},{ }^{24} \mathrm{PCs}$ are generally produced in blood groups $\mathrm{O}$ and A mainly with concern to the blood bank inventory, since 
these blood groups cover $\sim 90 \%$ of the population and administration of only $\mathrm{O}$ and $\mathrm{A}$ PCs for all patients reduces outdating of the units in the inventory. BCPCs contain small amounts of plasma. Blood group O BCPCs can therefore be transfused to A, B, and $\mathrm{AB}$ patients across $\mathrm{ABO}$ borders, lowtiter naturally occurring $\mathrm{ABO}$ antibodies being a prerequisite for this practice. However, it is debatable which titer is a low titer. ${ }^{24}$ Additionally, whether immunoglobulin (Ig)G or IgM or both titers are used and which technique is performed differ among the institutions. ${ }^{24}$ Some authors define high titer as $\geq 64$ for $\operatorname{IgM}$ and $\geq 256$ for $\operatorname{IgG},{ }^{25}$ but titers as low as 50 and as high as 512 have also been reported. ${ }^{26} \mathrm{~A}$ titer of 128 and even higher is also advocated because titers involved in acute hemolytic transfusion reactions (AHTRs) are much higher. ${ }^{26}$ At our institution, $\geq 250$ is defined as a high titer. $\mathrm{O}$ PCs are primarily transfused not only to $\mathrm{O}$ but also to $\mathrm{B}$ (minor ABO mismatch) patients, while A PCs are transfused mainly to blood group $\mathrm{A}$ and $\mathrm{AB}$ (minor $\mathrm{ABO}$ mismatch) patients. However, due to shortage of ABO-identical PCs at the blood bank inventory, O PCs may also be issued to A and $\mathrm{AB}$ (both minor $\mathrm{ABO}$ mismatch) patients and $\mathrm{A}$ PCs to $\mathrm{B}$ (bidirectional ABO mismatch) and $\mathrm{O}$ (major ABO mismatch) patients. Major ABO mismatch occurs when the patient has naturally occurring $\mathrm{ABO}$ antibodies against the $\mathrm{ABO}$ antigens of the PCs, and minor ABO mismatch occurs when there are naturally occurring $\mathrm{ABO}$ antibodies in the PCs against the patient's antigens. Both types of ABO mismatch may lead to mostly mild, if it happens at all, but also infrequently severe hemolytic transfusion reactions (HTRs). ${ }^{27}$

A2 donors have low amounts of A antigens on their platelets; therefore, by subtyping blood group A platelet apheresis donors for A1 and A2, blood banks can use A2 PCs as almost equivalent to blood group O PCs.

There are three different kinds of PCs, namely plateletrich plasma, BC, and APCs, that contain both plasma and additive solution. In-line leukocyte reduction filter removes leukocytes under production. Leukoreduction and less plasma content reduce the risk of transfusion reactions caused by leukocytes and plasma proteins, respectively. ${ }^{28}$ Although preparation of APCs is more expensive than the others, APCs are the only suitable PCs for patients with anti-human leukocyte antigen (HLA) and/or anti-human platelet antigen (HPA) antibodies, because platelets from HLA- and/or HPA-matched donors can be collected by platelet apheresis. Moreover, using APCs will contribute to limit the number of donors to which the patient will be exposed. This will reduce the risk of alloimmunization as well as transfusion-transmitted diseases, especially in pediatric patients. However, in the daily practice, providing enough APCs may be difficult, since collection takes longer time than whole blood donation and not all donors are eligible for apheresis. Patients who have prolonged $\mathrm{PC}$ requirements will be exposed to many donors anyway. APCs have been advocated to be superior to BCPCs, but in an earlier study, we showed that both BCPCs and APCs were equally effective with respect to posttransfusion platelet increments and transfusion intervals. ${ }^{23}$

\section{Indications and threshold for platelet transfusions}

Platelet transfusions are given on either a therapeutic or a prophylactic indication. Prophylactic transfusions account for the major amount of PCs administered to patients undergoing $\mathrm{HSCT}^{29}$ A recent Cochrane review did not find evidence that prophylactic transfusion policy prevents bleeding. ${ }^{29}$ There is ongoing discussion about the necessity of prophylactic platelet transfusions in patients with chronic thrombocytopenia..$^{30,31}$ The question is whether giving platelet transfusions only when patients have active bleeding can be followed as a strategy. This approach may reduce the number of platelet transfusions.

Thrombocytopenia alone does not necessarily require platelet transfusion, and prophylactic transfusions may even be contraindicated in some cases. ${ }^{32}$ Therefore, it is important to determine the reason for thrombocytopenia before transfusion. Avoiding unnecessary transfusions without risking a major bleeding that may have fatal outcome is important (Table 1). Management of patients with such restrictive transfusion strategy will also reduce the risk of immunization, development of refractoriness to platelet transfusions, transfusion-transmissible diseases, and other transfusion-associated complications (including transfusionrelated acute lung injury [TRALI] and transfusion-associated

\section{Table I Unnecessary transfusions}

\begin{tabular}{l} 
Red cell concentrates \\
Volume replacement/expansion \\
Hemoglobin $\geq 8 \mathrm{~g} / \mathrm{dL}$ unless active bleeding \\
Anemia due to: \\
Iron deficiency \\
$\quad$ Vitamin $\mathrm{B} / 2$ deficiency \\
$\quad$ Folic acid deficiency \\
PLT transfusions \\
PLT counts $\geq 20 \times 10^{9} / L^{a}$ unless active bleeding in stable patients \\
Immune thrombocytopenia unless active bleeding \\
Thrombotic thrombocytopenic purpura unless active bleeding \\
Heparin-induced thrombocytopenia unless active bleeding \\
\hline
\end{tabular}

Note: aHigher trigger (usually $50 \times 10^{9} / \mathrm{L}$ ) for central nerve system operations. Abbreviation: PLT, platelet. 
GvHD [TA-GvHD]). Hence, the main therapeutic indication for platelet transfusions is bleeding due to thrombocytopenia. Platelet transfusions may only have a minor and transient effect when thrombocytopenia is due to increased consumption/destruction (eg, primary immune thrombocytopenia), but achieving control on a severe bleeding will be time-saving before disease-specific treatment can be effective and platelet count starts increasing. ${ }^{32}$ Patients with qualitative (functional) platelet defects will need platelet transfusions with functionally normal platelets in case of bleeding. Patients with chronic hematological diseases such as elderly patients with myelodysplastic syndromes may have severe thrombocytopenia and be at risk of bleeding. However, curative treatment is not possible for many of these patients and no increase can be expected in their platelet counts. Prophylactic transfusions are then usually not recommended; therapeutic transfusions are given if bleeding occurs. Platelet transfusions are most effective when thrombocytopenia is because of chemotherapy-induced decreased platelet production. ${ }^{33}$ There is a general agreement that these patients are at risk of bleeding and should be transfused prophylactically. However, the transfusion threshold is controversial and there is lack of evidence that prophylactic transfusion prevents bleeding. ${ }^{29,34}$ Several randomized clinical studies have compared the threshold of $20 \times 10^{9} / \mathrm{L}$ platelets versus $10 \times 10^{9} / \mathrm{L}$ platelets, and concluded that a threshold of $10 \times 10^{9} / \mathrm{L}$ platelets in clinically stable patients has an acceptable safety. ${ }^{29,35} \mathrm{~A}$ higher limit for platelet transfusions, ie, $20 \times 10^{9} / \mathrm{L}$ platelets, is often recommended for patients with minor hemorrhage or with fever $>38^{\circ} \mathrm{C}$. Heparinized patients or patients with coagulopathy should receive prophylactic transfusion when platelet counts are at $10-30 \times 10^{9} / \mathrm{L}$. Finally, limits ranging from $20 \times 10^{9} / \mathrm{L}$ to $50 \times 10^{9} / \mathrm{L}$ platelets have been advocated before surgery or other invasive procedures such as spinal puncture. ${ }^{36}$

\section{Platelet dose}

The standard platelet dose given in one transfusion with an APC or a BCPC is $\sim 300-600 \times 10^{9} / \mathrm{L}$. Slichter et al defined low dose as $1.1 \times 10^{11} / \mathrm{L}$, medium dose as $2.2 \times 10^{11} / \mathrm{L}$, and high dose as $4.4 \times 10^{11} / \mathrm{L}$ per square meter of body surface area. ${ }^{37}$ There were no significant differences in bleeding, including grade 4 (Table 2), among the different groups of patients, where $41 \%$ were undergoing AHSCT. However, in the low-dose group, the number of platelet transfusions was increased..$^{37}$ In an earlier study, there were higher occurrences of grade 4 bleeding in patients receiving low-dose PCs, and this study was stopped. ${ }^{38}$
Table $2 \mathrm{WHO}$ bleeding grades

\begin{tabular}{ll}
\hline Grade & Signs \\
\hline 0 & No bleeding \\
I & $\begin{array}{l}\text { Petechia, ecchymosis, occult blood in body secretions, and } \\
\text { mild vaginal spotting }\end{array}$ \\
2 & $\begin{array}{l}\text { Gross bleeding not requiring RBC transfusions (eg, epistaxis, } \\
\text { hematuria, and hematemesis) }\end{array}$ \\
3 & Bleeding requiring RBC transfusions \\
4 & Life-threatening bleeding \\
\hline
\end{tabular}

Note: Data from Slichter. ${ }^{45}$

Abbreviations: RBC, red blood cell; WHO, World Health Organization.

What is the optimal parameter to evaluate the effect of platelet transfusions?

As platelet transfusions are given both prophylactically and therapeutically, clinical evaluations such as whether the patient has fever, infection/sepsis, is receiving any treatment with drugs with an impact on platelet counts and anticoagulation, is bleeding, and has splenomegaly or coagulopathy are to be made together with assessment of the transfusion effects. Cessation of major or macroscopic bleeding is easy to observe, but it does not necessarily mean that the transfusion has stopped the bleeding. ${ }^{39}$ In the therapeutic setting, posttransfusion platelet count in a bleeding patient is usually not increased significantly compared to the prophylactic transfusions when there is no bleeding.

1. Platelet count: Platelet count is the simplest way of measuring the risk of bleeding together with a clinical evaluation of the patient and should be required before the decision of platelet transfusion is made. However, low counts do not necessarily imply impending bleeding. A platelet count as close to transfusion as possible (pre-transfusion platelet count) can be used to compare with posttransfusion platelet count, the second one taken within an hour after the transfusion. A third platelet count measured 16-24 hours thereafter will contribute to further assessment of the effectiveness of the transfusion. ${ }^{39}$ This follow-up strategy is also useful in identifying patients who are or become immunized to HLA and/or HPAs in time.

2. Corrected count increment: Because the platelet content of PCs varies considerably, CCI may be a useful tool in the assessment of effectiveness of the PCs. CCI is calculated by using the following formula: ${ }^{40}$

(posttransfusion - pretransfusion platelet count) $\mathrm{CCI}=\frac{\left(10^{9} / \mathrm{L}\right) \times \text { body surface area }\left(\mathrm{m}^{2}\right)}{\text { number of platelets transfused }\left(10^{11}\right)}$

CCI-1 is calculated using posttransfusion platelet counts 1-2 hours and CCI-2 18-24 hours after platelet transfusion 
is completed. The generally accepted values for adequate CCI- 1 and CCI- 2 are 7.5 and 4.5 , respectively. ${ }^{40} \mathrm{CCI}$ for assessing transfusion efficacy is controversial, because it does not provide information about the functional status of the platelets. A fully adequate and appropriate test that can evaluate the hemostatic function of a PC is not yet available; hence, $\mathrm{CCI}$ as a surrogate score may be preferred.

3. Survival of the transfused platelets: Radioisotope labeling methods are not in clinical use..$^{41}$ Recently, a flow cytometric method based on HLA type differences between the donor and the patient was described in patients undergoing AHSCT. ${ }^{42}$ This method is used to detect platelet recovery, survival, and engraftment.

4. Transfusion intervals: Several groups have used the time interval between transfusions to assess transfusion efficacy. ${ }^{23,43,44}$ Slichter et al ${ }^{37}$ observed a relationship between increased platelet increments and prolonged transfusion intervals, ie, higher platelet increments resulting in prolonged transfusion intervals. We and another group confirmed this finding. ${ }^{23,43,44}$ Transfusion intervals in the prophylactic setting depend on the platelet dose, with longer intervals indicating reduced transfusion requirements.

5. Bleeding score: The World Health Organization bleeding grades are shown in Table $2 .{ }^{45}$ Based on this score, evidence of bleeding can be assessed to evaluate the patient both before and after transfusion and in the follow-up period. ${ }^{38}$

The clinical value of platelet recovery and bleeding time is controversial and will not be discussed here. CCI and transfusion intervals were used in the study mentioned earlier ${ }^{23} \mathrm{CCI}$, because it is the most used measurement and transfusion intervals, because of its practical and clinical importance.

\section{Special procedures Leukoreduction of blood components}

During the production of RCCs and PCs, leukocyte depletion by filtration (Table 3 ) is needed to achieve the quality generally accepted and also required by the Council of Europe's standard, ie, $<0.2 \times 10^{6}$ residual leukocytes per unit of PC. ${ }^{46}$ Prestorage depletion within 6 hours from production is recommended to avoid cytokine secretion from the leukocytes during storage, because cytokines are regarded as responsible for febrile non-HTRs (FNHTR). ${ }^{47}$ Thus, the incidence of FNHTR could be reduced by using leukodepleted components. APCs are leukoreduced during the processing either by filtration in connection to the cell separator or by a built-in technology that uses size and density differences between platelets and leukocytes to eliminate leukocytes. Removing leukocytes and irradiating blood components reduce the risk of HLA immunization by contaminating lymphocytes. ${ }^{48,49}$ However, alloimmunization may still be an issue in patients receiving leukodepleted components; mostly in women probably immunized as a consequence of previous pregnancies. ${ }^{50}$ Immunized patients should then receive HLA-matched or cross-matched APCs. In our institution, we have been using Luminex $^{\circledR}$ analysis to select donors who do not express HLA antigens against which the patient has antibodies (unpublished data). Universal leukoreduction has been controversial; while some countries use leukoreduced blood components

Table 3 Special procedures

\begin{tabular}{|c|c|c|c|}
\hline & Purpose & Principle & Indication \\
\hline Leukoreduction & $\begin{array}{l}\text { To reduce the leukocyte } \\
\text { content of cellular blood } \\
\text { components }\end{array}$ & $\begin{array}{l}\text { - By filtration during blood component } \\
\text { production } \\
\text { - Cell separators that can differentiate } \\
\text { and eliminate leukocytes }\end{array}$ & $\begin{array}{l}\text { - Patients who have had FNHTR } \\
\text { - Patients at risk of alloimmunization; } \\
\text { against both blood group antigens and } \\
\text { HLA antigens } \\
\text { - Patients at risk of cytomegalovirus } \\
\text { infection }\end{array}$ \\
\hline $\begin{array}{l}\text { Irradiation/pathogen- } \\
\text { reduction technologies }\end{array}$ & To prevent TA-GvHD & $\begin{array}{l}\text { Preventing proliferation of the viable } \mathrm{T} \\
\text { lymphocytes in the blood component }\end{array}$ & $\begin{array}{l}\text { - Patients undergoing AHSCT } \\
\text { - HLA-matched blood components }\end{array}$ \\
\hline $\begin{array}{l}\text { Volume reduction and } \\
\text { washing }\end{array}$ & $\begin{array}{l}\text { To reduce the plasma } \\
\text { amount of the blood } \\
\text { component }\end{array}$ & Plasma depletion and washing with saline & $\begin{array}{l}\text { - Neonatal/pediatric patients with } \\
\text { volume overload issues } \\
\text { - IgA-deficient patients with anti-lgA } \\
\text { antibodies } \\
\text { - Patients who have had serious allergic/ } \\
\text { anaphylactic reactions due to plasma } \\
\text { proteins in blood components }\end{array}$ \\
\hline
\end{tabular}

Abbreviations: AHSCT, allogeneic hematopoietic stem cell transplantation; FNHTR, febrile non-hemolytic transfusion reactions; HLA, human leukocyte antigen; IgA, immunoglobulin A; TA-GvHD, transfusion-associated graft-versus-host disease. 
only for patients with long-term transfusion requirements probably mainly due to economic concerns, some others, including Norway, have implemented universal leukoreduction of all cellular components. ${ }^{20}$ Finally, leukoreduction is also beneficial for reducing the risk of cytomegalovirus transmission in patients undergoing allogeneic stem cell transplantation (Table 3 ). ${ }^{51}$

\section{Irradiation of the blood components}

Patients undergoing AHSCT should be transfused with irradiated cellular components, ie, RCCs and PCs, in order to prevent TA-GvHD (Table 3). ${ }^{52}$ According to the national guidelines in Norway, irradiation should be performed 1 month before AHSCT and continued at least 1 year after. ${ }^{20}$ TA-GvHD is a severe complication that occurs when viable $\mathrm{T}$ lymphocytes of a blood donor engraft and proliferate in the transfused patient, attack the patient's antigen-presenting tissue, and cause injury. Mortality rate up to $100 \%$ occurs because BM is also attacked by T lymphocytes, unlike GvHD related to AHSCT. ${ }^{53}$ HLA-compatible PCs must also be irradiated to prevent TA-GvHD at all times. Platelet units treated by pathogen-reduction technologies have been considered as effective as irradiation, since these methods also prevent T-lymphocyte proliferation. ${ }^{52}$ However, there are concerns about whether the in vitro properties of the pathogen-reduced PCs are diminished in PCs stored for more than 5 days. ${ }^{54}$ A recent Cochrane report found no evidence of differences in clinical outcomes between pathogen-reduced and standard PCs, but a range of laboratory outcomes indicated some benefits for the standard PCs. ${ }^{55}$ There is still a need for further trials to establish the position of pathogen reduction of blood components in transfusion practice.

\section{Volume reduction and washing}

Blood components can be volume reduced by depleting plasma (Table 3). Neonatal and other pediatric patients will by this means be provided a high number of platelets with lower risk of circulatory overload as well as reduced risk of plasma-related transfusion reactions. ${ }^{56}$ Washing the unit with saline several times may be indicated for 1) patients with IgA deficiency and anti-IgA antibodies and 2) patients who have had serious allergic/anaphylactic reactions due to plasma proteins.

\section{Transfusion complications}

Transfusion complications are the main reasons for the recommendation of restrictive transfusion policy. Not all transfusion complications are reviewed in this article in detail, but a special emphasis is given on the most relevant complications in AHSCT patients (Table 4). Differential diagnosis between the underlying disease, side effects of the treatment, and transfusions may be a challenge, but considering transfusion as a possible reason for the clinical picture will be valuable.

\section{Acute hemolytic transfusion reactions}

AHTRs have a fatality rate of $10 \%-40 \%$ and occur mainly due to clerical errors when an incorrect blood component is transfused to the wrong patient (Table 4) ${ }^{57}$ Some blood group antibodies may weaken in time and may not be detectable in a screened sample. From 3 days to 30 days after transfusion of an antigen-positive red cell unit, and sometimes when the patient is no longer admitted to hospital, hemolysis (delayed HTR) due to an anamnestic antibody response (mostly Kidd antibodies anti-Jka or anti-Jkb) may occur with mild symptoms.

\section{Febrile non-hemolytic transfusion reactions}

As mentioned earlier, FNHTRs have been significantly reduced after the implementation of leukoreduction of blood components. FNHTRs are generally benign (Table 4). However, they may be very unpleasant for the patient. Repetitive FNHTRs can imply HLA immunization. If FNHTRs occur together with refractoriness after platelet transfusions, the patient should be investigated regarding anti-HLA- and/or HPA-antibodies.

\section{Allo- and autoimmunization}

Foreign antigens from a blood, stem cell or solid organ donor are presented to the patients by transfusion and transplantation. In pregnancy, the paternal antigens, which the fetus has inherited and thus may be foreign to the mother, may pass the placenta due to fetomaternal hemorrhage. These foreign antigens can lead to immunization against RBC, platelet, and/or leukocyte antigens. Not all antibodies have clinical significance (Table 4), ${ }^{58}$ but those that have must be taken into consideration when the patients need red cells and/or PCs.

Irregular blood group antibodies (alloantibodies) Irregular blood group antibodies can be detected by routine screening before transfusion (type and screen; Table 4), and cross-matched red cells will then shortly be issued, unless the antibodies are "challenging" ones. Clinically significant alloantibodies against high frequency antigens, ie, antigens present in a very high percent (up to $99 \%-99.99 \%$ ) of the 
Table 4 Transfusion complications

\begin{tabular}{|c|c|c|c|c|}
\hline $\begin{array}{l}\text { Transfusion } \\
\text { complications }\end{array}$ & Cause & Clinical presentation/features & $\begin{array}{l}\text { Preventive measures and } \\
\text { management }\end{array}$ & References \\
\hline $\begin{array}{l}\text { Acute hemolytic } \\
\text { transfusion reactions }\end{array}$ & $\begin{array}{l}\text { Mostly due to clerical errors, } \\
\text { incorrect blood component, } \\
\text { ie, an } \mathrm{ABO} \text {-incompatible unit is } \\
\text { transfused to the wrong patient }\end{array}$ & $\begin{array}{l}\text { Fever, disseminated intravascular } \\
\text { hemolysis, flank pain, and } \\
\text { hemoglobinuria. Hemoglobin } \\
\text { and haptoglobin values fall, while } \\
\text { bilirubin and lactate dehydrogenase } \\
\text { increase }\end{array}$ & $\begin{array}{l}\text { - Patient identification } \\
\text { - Verification of the correct patient } \\
\text { for whom the blood component } \\
\text { is required } \\
\text { - Verification of correct unit for } \\
\text { this patient } \\
\text { - Control of blood groups of the } \\
\text { patient and the blood component }\end{array}$ & 57,70 \\
\hline $\begin{array}{l}\text { Febrile nonhemolytic } \\
\text { transfusion reactions }\end{array}$ & $\begin{array}{l}\text { - Cytokines released from residual } \\
\text { leukocytes in blood components } \\
\text { - Repetitive FNHTR can imply } \\
\text { HLA immunization }\end{array}$ & $\begin{array}{l}\text { Fever may also be a component } \\
\text { of other more serious transfusion } \\
\text { complications. Until investigation } \\
\text { of the reaction is completed, the } \\
\text { transfusion has to be stopped and } \\
\text { the patient must be monitored } \\
\text { closely }\end{array}$ & $\begin{array}{l}\text { - Leukoreduction of the blood } \\
\text { components } \\
\text { - If fever together with } \\
\text { refractoriness occurs after platelet } \\
\text { transfusions, anti-HLA and/or } \\
\text { anti-HPA antibodies of the patient } \\
\text { should be investigated }\end{array}$ & $48,49,80$ \\
\hline Alloimmunization & $\begin{array}{l}\text { Foreign antigens from the cellular } \\
\text { blood components or former } \\
\text { immunization after pregnancy or } \\
\text { transplantation }\end{array}$ & $\begin{array}{l}\text { Clinically significant antibodies } \\
\text { may cause hemolysis if antigen- } \\
\text { positive red cells are transfused. } \\
\text { Alloimmunization to HLA and/ } \\
\text { or HPA antigens may cause } \\
\text { refractoriness to platelet } \\
\text { transfusions }\end{array}$ & $\begin{array}{l}\text { - Pre-transfusion antibody screen } \\
\text { and transfusion with antigen- } \\
\text { negative red cells. } \\
\text { - Providing HLA- and/or HPA- } \\
\text { compatible platelets }\end{array}$ & $48,49,58,63$ \\
\hline TTI & $\begin{array}{l}\text { Viral (eg, hepatitis B and C, HIV, } \\
\text { and dengue virus), bacterial } \\
\text { (eg, skin bacteria or gram-negative } \\
\text { bacteria), and parasitic (eg, malaria } \\
\text { and Trypanosoma cruzi) pathogens }\end{array}$ & $\begin{array}{l}\text { Despite serological tests performed } \\
\text { for every donation, TTI is still a } \\
\text { transfusion safety issue especially } \\
\text { when, for instance, malaria infection } \\
\text { is not suspected if the patient has } \\
\text { not traveled outside the country for } \\
\text { a long time period or ever }\end{array}$ & $\begin{array}{l}\text { - Donor questionnaire at every } \\
\text { donation } \\
\text { - Deferral in case of risk behavior } \\
\text { or risk of infections } \\
\text { - Diversion method } \\
\text { - Bacterial detection systems for } \\
\text { PCs }\end{array}$ & $69,81-83$ \\
\hline TACO & Volume overload & $\begin{array}{l}\text { Elderly, pregnant women, and } \\
\text { pediatric patients are at risk even } \\
\text { after transfusion of small amounts } \\
\text { of blood components }\end{array}$ & $\begin{array}{l}\text { - Adjustment of transfusion speed } \\
\text { and volume according to patient's } \\
\text { blood volume. } \\
\text { - Consider diuretics unless } \\
\text { contraindicated }\end{array}$ & 70,84 \\
\hline Allergic reactions & $\begin{array}{l}\text { Allergens such as food, drugs } \\
\text { in plasma of the blood unit } \\
\text { and patients' antibodies to } \\
\text { plasma proteins such as IgA } \\
\text { and haptoglobin }\end{array}$ & $\begin{array}{l}\text { Itching, rash, urticaria, wheezing, } \\
\text { and facial edema may occur. } \\
\text { Anaphylaxis is seldom but may } \\
\text { be life-threatening. For a brief } \\
\text { discussion, refer to Hirayama's } \\
\text { review paper }{ }^{71}\end{array}$ & $\begin{array}{l}\text { - Reducing the amount of plasma in } \\
\text { blood components either under } \\
\text { production or before transfusion } \\
\text { - Desensitization }\end{array}$ & $7 I-73,85$ \\
\hline TR-GvHD & $\begin{array}{l}\text { Viable T lymphocytes in the blood } \\
\text { unit. T lymphocytes engraft and } \\
\text { proliferate in the recipient, and } \\
\text { thereafter cause tissue injury }\end{array}$ & $\begin{array}{l}\text { From } 3 \text { days to } 30 \text { days after } \\
\text { transfusion, rash, fever, diarrhea, } \\
\text { cholestasis, nausea, and vomiting } \\
\text { may occur. Pancytopenia can be } \\
\text { severe. Mortality is } 90 \%\end{array}$ & $\begin{array}{l}\text { - Irradiation of the cellular blood } \\
\text { components in order to prevent } \\
\text { lymphocyte proliferation } \\
\text { - Using pathogen reduction } \\
\text { technology }\end{array}$ & 52,86 \\
\hline TRALI & $\begin{array}{l}\text { Antibody-mediated (anti-HLA class } \\
\text { I and II and HNA antibodies) and } \\
\text { nonantibody-mediated TRALI. } \\
\text { TRALI is the major cause of } \\
\text { transfusion-related mortality. } \\
\text { Even though there are only case } \\
\text { reports about TRALI in patients } \\
\text { undergoing AHSCT, it may be } \\
\text { underdiagnosed }\end{array}$ & $\begin{array}{l}\text { This is an ARDS. Dyspnea, cyanosis, } \\
\text { hypotension, fever, and hypoxia } \\
\text { within } 6 \text { hours after transfusion }\end{array}$ & $\begin{array}{l}\text { - Testing female donors who have } \\
\text { been pregnant for anti-HLA } \\
\text { antibodies. Defer donors with } \\
\text { antibodies } \\
\text { - Using only male donors } \\
\text { - Supportive treatment, eg, with } \\
\text { mechanical ventilation as any } \\
\text { other ARDS }\end{array}$ & $74,75,86$ \\
\hline
\end{tabular}


Table 4 (Continued)

\begin{tabular}{|c|c|c|c|c|}
\hline $\begin{array}{l}\text { Transfusion } \\
\text { complications }\end{array}$ & Cause & Clinical presentation/features & $\begin{array}{l}\text { Preventive measures and } \\
\text { management }\end{array}$ & References \\
\hline PTP & $\begin{array}{l}\text { Platelet antibodies, mostly anti-HPA } \\
\text { la in a HPA-Ibb patient after } \\
\text { former pregnancy or transfusion }\end{array}$ & $\begin{array}{l}\text { Severe thrombocytopenia within } \\
7-10 \text { days after transfusion of } \\
\text { HPA-Ia platelet containing blood } \\
\text { components. Petechia, purpura, and } \\
\text { mucosal bleed }\end{array}$ & $\begin{array}{l}\text { - Providing HPA-Ibb blood } \\
\text { components } \\
\text { - Leukoreduction of blood } \\
\text { components has reduced the } \\
\text { number of PTP cases }\end{array}$ & $70,86,87$ \\
\hline Iron load & $\begin{array}{l}\text { Excess iron from many red cell } \\
\text { transfusions }\end{array}$ & $\begin{array}{l}\text { Even after 10-20 transfusions, } \\
\text { deposition in parenchymal } \\
\text { tissues causes hepatomegaly, } \\
\text { liver dysfunction, heart failure, } \\
\text { hypogonadism, diabetes mellitus, } \\
\text { pigmentation, and arthropathy }\end{array}$ & $\begin{array}{l}\text { - Preventing unnecessary } \\
\text { transfusions } \\
\text { - Iron chelation }\end{array}$ & 76,86 \\
\hline
\end{tabular}

Abbreviations: AHSCT, allogeneic hematopoietic stem cell transplantation; ARDS, adult respiratory distress syndrome; FNHTR, febrile non-hemolytic transfusion reactions; HLA, human leukocyte antigen; HNA, human neutrophil antigen; HPA, human platelet antigen; IgA, immunoglobulin A; PCs, platelet concentrates; PTP, posttransfusion purpura; TACO, transfusion-associated circulatory overload; TRALI, transfusion-related acute lung injury; TR-GvHD, transfusion-related graft versus host disease; TTI, transfusion-transmitted infections.

population, mean that antigen-negative blood donors are very rare. Thus, to find the negative blood units may be challenging. The blood bank will then try to provide antigen-negative red cell units. However, it is not an easy task when the antigen-negative donors and units are very rare. There are several centers in the world that have frozen units with such rare antigen-negative red cells. Patients who have multiple antibodies may also present some difficulties. Good communication between the blood bank and the clinical department is essential then, in order to have a common understanding of the challenges and plan the transfusions.

\section{Blood group alloimmunization due to incompatible PCs}

Platelets do not express D antigen on their membrane, but variable amounts (yet few) of $\mathrm{ABO}$ antigens. ${ }^{59} \mathrm{PCs}$, however, contain small amounts of red cells that may induce immunization against blood group antigens, including Rh antigens. ${ }^{50}$ The amount of contaminating red cells in APCs is $<34$ cells $/ \mu \mathrm{L}$, which varies between $0.00017 \mathrm{~mL}$ and $3.00 \mathrm{~mL},{ }^{24,60}$ and between $0.036 \mathrm{~mL}$ and $0.59 \mathrm{~mL}$ in BCPCs. ${ }^{24}$ We do not know the exact amount of red cells that can be sufficient to immunize a patient, but as low as $0.03 \mathrm{~mL}$ was reported to be immunogenic. ${ }^{61}$ Hence, blood banks should continue labeling PCs as RhD negative and positive. PCs that are obviously (macroscopically reddish) contaminated with red cells should not be used. Preventing immunization against $\mathrm{D}$ is especially important in female patients of childbearing age and younger girls because of future pregnancies where anti-D antibody will bring the risk of hemolytic disease of a D-positive fetus and newborn. These patients should therefore receive D-negative
PCs; if not, prophylaxis with anti-D immune globulin is recommended. ${ }^{62}$ How necessary anti-D prophylaxis is also controversial, because several groups have reported low immunization rate owing to more advanced PC production techniques. ${ }^{63,64}$ Should hematological patients with longterm transfusion requirements also be treated/categorized in the same way is not finally established.

\section{HLA and HPA immunization/refractoriness to platelet transfusion}

Leukoreduction of cellular blood components reduces the risk of alloimmunization but does not eliminate it (Table 4). ${ }^{48}$ Thus, transfusion as well as pregnancy and transplantation may lead to alloimmunization against HLA and/or HPA antigens. Platelets express HLA class I antigens (HLA-A, HLA-B) and HPA. Strong and/or broad-spectrum anti-HLA and anti-HPA antibodies induce refractoriness (to platelet transfusions), which is defined as insufficient platelet count increments after two adequate platelet transfusions when no clinical factor can explain the lack of increment. ${ }^{44}$ Then, the investigation to detect anti-HLA and/or anti-HPA antibodies is necessary. When platelet transfusion is indicated, patients with anti-HLA and -HPA antibodies are prone to bleeding unless compatible PCs are provided. There are several strategies for providing compatible platelet donors. At our institution Luminex ${ }^{\circledR}$-based antibody profile of the patient is employed to choose antigen negative donors. This strategy contributes in increasing the number of compatible platelet donors. Other strategies include cross-match and cross-reactive antigen group matching. ${ }^{62}$ 


\section{Autoantibodies}

Autoimmune hemolytic anemia occurring after AHSCT is an infrequent complication (3.6\%) that may be resistant to the conventional steroid therapy and have a higher mortality (36\%). ${ }^{65,66}$ Red cell transfusions may trigger autoantibody formation. ${ }^{67}$ When transfusion is needed, the blood bank should investigate the blood sample with adsorption techniques to reveal an eventual underlying alloantibody(ies), because alloantibodies are found in $28 \%-34 \%$ of the patients who have autoantibodies. ${ }^{67,68}$ Identification of the alloantibody(ies) is important in order to issue antigennegative blood. Further immunization should be prevented with restrictive transfusion strategy, but transfusions when necessary should not be omitted.

\section{Transfusion-transmitted infections}

Despite serological tests performed for every donation, transfusion-transmitted infection is still a transfusion safety issue due to several viral (eg, hepatitis B and C, HIV, and dengue virus), bacterial (eg, skin bacteria or gram-negative bacteria), and parasitic (eg, malaria and Trypanosoma cruzi) pathogens (Table 4). ${ }^{69}$

\section{Transfusion-associated circulatory overload}

Elderly, pregnant women, and pediatric patients are at risk even after transfusion of small amounts of blood components (Table 4). ${ }^{70}$

\section{Allergic reactions}

Allergic reactions may be mild or severe. Anaphylaxis is seldom but may be life-threatening. Hirayama's review paper ${ }^{71}$ provides a brief discussion on this issue (Table 4).

Desensitization by serial exposure to platelets is hypothesized to diminish the risk of severe allergic reactions in patients who have had such reactions. This is based on the observation that severe urticarial and anaphylactic reactions may occur earlier during serial platelet transfusions. ${ }^{72}$ Continuous infusion by increasing concentrations of IgA-enriched Ig preparation is reported to be successful in a patient who had had anaphylaxis due to IgA deficiency and anti-IgA. By achieving desensitization, the patient could then be transfused by standard blood components without any complications. ${ }^{73}$

\section{Transfusion-related GvHD}

Transfusion-related GvHD has been discussed earlier under the "Irradiation of the blood components" section (Table 4).

\section{Transfusion-related acute lung injury}

Antibody-mediated and non-antibody-mediated TRALI are the two groups of this condition, which are the major causes of transfusion-related mortality. ${ }^{74,75}$ Even though there are only case reports about TRALI in patients undergoing AHSCT, it may be underdiagnosed (Table 4).

\section{Posttransfusion purpura}

Leukoreduction of blood components have reduced the number of posttransfusion purpura cases (Table 4). ${ }^{70}$

\section{Iron load}

Patients with hematological malignancies and hemoglobinopathies may have already received many transfusions before AHSCT, and iron load following many transfusions with PRCs may be a risk factor for increased non-relapse mortality after AHSCT (Table 4) ${ }^{76}$

\section{Blood group incompatibility in AHSCT}

Blood group incompatibility is not a hindrance to AHSCT, because HLA compatibility is the major concern. ${ }^{77} \mathrm{ABO}$ mismatch exists in $30 \%-40 \%$ of cases undergoing AHSCT. ${ }^{78}$

Incompatibility involving other blood group systems is also reported. ${ }^{78}$ Blood group incompatibility does not delay neutrophil and platelet engraftment, does not increase the risk of graft rejection and GvHD, and finally does not have deleterious effects on overall survival. ${ }^{79}$ However, there are several complications due to incompatibility (Table 5).

Blood group incompatibility is classified according to the direction of blood group antibodies, antibodies directed to the patient's red cell antigens or to the donor's, as follows:

- Major ABO incompatibility is the case when the patient has red cell antibodies directed to the donor's red cell antigens (eg, donor is blood group A, patient is blood group $\mathrm{O}$, and patient's naturally occurring anti- $\mathrm{A}$ is the reason for incompatibility).

- Minor ABO incompatibility is the case when the donor has red cell antibodies directed to the patient's red cell antigens (eg, patient is blood group A, donor is blood group $\mathrm{O}$, and donor's naturally occurring anti-A is the reason for incompatibility).

- Bidirectional ABO incompatibility is the case when both the patient and the donor have red cell antibodies directed to each other's red cell antigens (eg, patient is blood group A, donor is blood group B, and patient's naturally occurring anti-B together with donor's naturally occurring anti-A are the reasons for incompatibility). 
Table 5 Types of blood group incompatibility, the reason of the incompatibility, complications due to incompatibility, and the management of the complications

\begin{tabular}{llllll}
\hline & Antibody & Antigen & $\begin{array}{l}\text { Reason of the } \\
\text { incompatibility }\end{array}$ & Complications & Management \\
\hline $\begin{array}{l}\text { Major } \\
\text { incompatibility }\end{array}$ & Patient & Donor & Patient's antibody & $\begin{array}{l}\text { Immediate severe } \\
\text { hemolytic reaction } \\
\text { Delayed RBC } \\
\text { engraftment (PRCA) }\end{array}$ & $\begin{array}{l}\text { RBC depletion from the transplant, if the } \\
\text { antibody titer is high } \\
\text { Plasma exchange, donor lymphocyte infusion, } \\
\text { cyclosporine withdrawal, erythropoietin, and } \\
\text { rituximab }\end{array}$ \\
$\begin{array}{l}\text { Minor } \\
\text { incompatibility }\end{array}$ & Donor & Patient & Donor's antibody & $\begin{array}{l}\text { Delayed hemolysis } \\
\text { (passenger lymphocyte } \\
\text { slandrome }\end{array}$ & $\begin{array}{l}\text { Pastibody titer is high } \\
\text { antirectional } \\
\text { incompatibility }\end{array}$ \\
\hline
\end{tabular}

Abbreviations: PRCA, pure red cell aplasia; RBC, red blood cell.

\section{How to choose blood components when there is $A B O$ incompatibility between the patient and the donor?}

The primary objective is to ensure that RCCs, PCs, and plasma are $\mathrm{ABO}$ compatible with both the patient and the donor (Table 6). It is recommended to continue this strategy at least until red cell engraftment occurs in order not to risk

Table 6 List of which blood type the blood component should be when there is $A B O$ mismatch between the patient and the donor

\begin{tabular}{|c|c|c|c|c|}
\hline Patient & Donor & RCC & PC & Plasma \\
\hline \multicolumn{5}{|c|}{ Major $A B O$ mismatch } \\
\hline 0 & A & O & $\mathrm{A} 2$ or $\mathrm{O}$ (low titer of anti-A) & $A, A B$ \\
\hline O & B & O & $\mathrm{A} 2$ or $\mathrm{O}$ (both low titer of anti-B) & $B, A B$ \\
\hline O & $A B$ & O & $\begin{array}{l}\text { O (low titers of anti-A and anti-B), } \\
\text { A2 (low titer of anti-B) }\end{array}$ & $A B$ \\
\hline A & $A B$ & $\mathrm{~A}, \mathrm{O}$ & $\begin{array}{l}\text { A (low titer of anti-B), } \\
\text { O (low titers of anti-A and anti-B) }\end{array}$ & $A B$ \\
\hline B & $A B$ & $\mathrm{~B}, \mathrm{O}$ & $\begin{array}{l}\text { O (low titers of anti-A and anti-B), } \\
\text { A2 (low titer of anti-B) }\end{array}$ & $A B$ \\
\hline \multicolumn{5}{|c|}{ Minor ABO mismatch } \\
\hline A & O & O & $\mathrm{A}, \mathrm{O}$ (low titer of anti-A) & $A, A B$ \\
\hline B & O & O & O or A2 (both low titer of anti-B), B & $B, A B$ \\
\hline$A B$ & O & O & $\begin{array}{l}\text { A (low titer of anti-B), } \\
O \text { (low titers of anti-A and anti-B) }\end{array}$ & $A B$ \\
\hline$A B$ & A & $\mathrm{A}, \mathrm{O}$ & $\begin{array}{l}\text { A (low titer of anti-B), } \\
O \text { (low titers of anti-A and anti-B), } \\
B \text { (low titer of anti-A), } A B\end{array}$ & $A B$ \\
\hline$A B$ & B & $\mathrm{B}, \mathrm{O}$ & $\begin{array}{l}\text { (low titers of anti-A and anti-B), } \\
A \text { (low titer of anti-B), } \\
B \text { (low titer of anti-A), AB }\end{array}$ & $A B$ \\
\hline \multicolumn{5}{|c|}{ Bidirectional $A B O$ mismatch } \\
\hline$A$ & B & O & $\begin{array}{l}\text { O (low titers of anti-A and anti-B), } \\
\text { A (low titer of anti-B) }\end{array}$ & $A B$ \\
\hline B & $A$ & O & $\begin{array}{l}\text { (low titers of anti-A and anti-B), } \\
\text { A2 (low titer of anti-B), } \\
\text { A (low titer of anti-B) }\end{array}$ & $A B$ \\
\hline
\end{tabular}

Abbreviations: PC, platelet concentrate; RCC, red cell concentrate.
HTRs. At our institution, we continue issuing components compatible with both the patient and the donor as long as the patient needs transfusions. In case of hematological malignancy relapse, the patient's original blood type may also "relapse". If the recipient or the donor is D negative, especially for a female patient of childbearing age ( $<50$ years), D-negative units should be issued in order not to immunize the patient. If D-negative PCs are not available, then anti-D prophylaxis is recommended. ${ }^{6}$ Depending on the availability of HLA-compatible donors, HLA compatibility is prioritized instead of ABO compatibility. It is then important to choose donors with low-titer $\mathrm{ABO}$ antibodies or remove plasma by washing procedures at the blood bank if the donor has hightiter antibodies, as discussed earlier.

\section{Conclusion}

Red cell and platelet transfusions constitute an important part of the supportive therapy for patients undergoing AHSCT. Disease- and treatment-related anemia and thrombocytopenia are the main indications for red cell and platelet transfusions, respectively. Red cell transfusion triggers are not fully established for patients undergoing AHSCT. Evaluation of the whole patient is essential. Nevertheless, hemoglobin values $\leq 6-7 \mathrm{~g} / \mathrm{dL}$ together with evident anemia symptoms will justify transfusion, preferably one unit at a time. Platelet transfusions may be given both prophylactically and therapeutically; however, whether the prophylactic transfusions are necessary at all is an ongoing debate. Relevant clinical information and follow-up platelet count 1 hour after the transfusion will contribute to further investigation at the blood bank when refractoriness to platelet transfusions is suspected. A close cooperation between the hematologists and the transfusion medicine specialists is therefore required to optimize the transfusion policy 
including selection of the correct blood component for the correct indication. Both undertransfusion and unnecessary transfusions must be avoided.

\section{Disclosure}

The author reports no conflicts of interest in this work.

\section{References}

1. Gooley TA, Chien JW, Pergam SA, et al. Reduced mortality after allogeneic hematopoietic-cell transplantation. $N$ Engl $J$ Med. 2010;363(22):2091-2101.

2. Holtick U, Albrecht M, Chemnitz JM, et al. Bone marrow versus peripheral blood allogeneic haematopoietic stem cell transplantation for haematological malignancies in adults. Cochrane Database Syst Rev. 2014;4:CD010189.

3. Aung FM, Lichtiger B, Bassett RL, Hosing C, Freireich EJ. Granulocyte concentrates from a single high-yield apheresis can be split to support multiple patients. Leuk Lymphoma. 2014;55(11):2577-2583.

4. Estcourt LJ, Stanworth S, Doree C, et al. Granulocyte transfusions for preventing infections in people with neutropenia or neutrophil dysfunction. Cochrane Database Syst Rev. 2015;(6):CD005341.

5. Oza A, Hallemeier C, Goodnough L, et al. Granulocyte-colonystimulating factor-mobilized prophylactic granulocyte transfusions given after allogeneic peripheral blood progenitor cell transplantation result in a modest reduction of febrile days and intravenous antibiotic usage. Transfusion. 2006;46(1):14-23.

6. Liesveld J, Pawlowski J, Chen R, et al. Clinical factors affecting engraftment and transfusion needs in SCT: a single-center retrospective analysis. Bone Marrow Transplant. 2013;48(5):691-697.

7. Zhang X, Xiao Y, Ran Q, et al. Clinical observation of factors in the efficacy of blood component transfusion in patients following hematopoietic stem cell transplantation. PLoS One. 2012;7(5):e36912.

8. Kekre N, Chou A, Tokessey M, et al. Storage time of transfused red blood cells and impact on clinical outcomes in hematopoietic stem cell transplantation. Transfusion. 2011;51(11):2488-2494.

9. Richard S, Schuster MW. Stem cell transplantation and hematopoietic growth factors. Curr Hematol Rep. 2002;1(2):103-109.

10. Martino M, Lanza F, Demirer T, Moscato T, Secondino S, Pedrazzoli P. Erythropoiesis-stimulating agents in allogeneic and autologous hematopoietic stem cell transplantation. Expert Opin Biol Ther. 2015;15(2):195-211.

11. Bormanis J, Quirt I, Chang J, et al. Erythropoiesis-stimulating agents (ESAs): do they still have a role in chemotherapy-induced anemia (CIA)? Crit Rev Oncol Hematol. 2013;87(2):132-139.

12. Xenocostas A, Yee A, Wong CJ, et al. RBC transfusion requirements after allogeneic marrow transplantation: impact of the before-transplant $\mathrm{Hb}$ level on transfusion and early survival. Transfusion. 2003;43(3):373-382.

13. Aung FM, Lichtiger B, Bassett R, et al. Incidence and natural history of pure red cell aplasia in major ABO-mismatched haematopoietic cell transplantation. Br J Haematol. 2013;160(6):798-805.

14. Carson JL, Grossman BJ, Kleinman S, et al. Red blood cell transfusion: a clinical practice guideline from the AABB*. Ann Intern Med. 2012; 157(1):49-58.

15. Retter A, Wyncoll D, Pearse R, et al; British Committee for Standards in Haematology. Guidelines on the management of anaemia and red cell transfusion in adult critically ill patients. Br J Haematol. 2013;160(4):445-464.

16. Bercovitz RS, Quinones RR. A survey of transfusion practices in pediatric hematopoietic stem cell transplant patients. J Pediatr Hematol Oncol. 2013;35(2):e60-e63.

17. Lightdale JR, Randolph AG, Tran CM, et al. Impact of a conservative red blood cell transfusion strategy in children undergoing hematopoietic stem cell transplantation. Biol Blood Marrow Transplant. 2012;18(5):813-817.
18. Berger MD, Gerber B, Arn K, Senn O, Schanz U, Stussi G. Significant reduction of red blood cell transfusion requirements by changing from a double-unit to a single-unit transfusion policy in patients receiving intensive chemotherapy or stem cell transplantation. Haematologica. 2012;97(1):116-122.

19. Tay J, Tinmouth A, Fergusson D, Allan D. Transfusion of red cells in hematopoietic stem cell transplantation (TRIST): study protocol for a randomized controlled trial. Trials. 2011;12:207.

20. National guidelines for transfusion medicine services in Norway. 42-43. Available from: https://helsedirektoratet.no/retningslinjer/veileder-fortransfusjonstjenesten-i-norge. Accessed March 27, 2016.

21. Solheim BG. Provision of K- (KEL1-) blood to women not more than 50 years of age. Transfusion. 2015;55(3):468-469.

22. Larsen CP, Ezligini F, Hermansen NO, Kjeldsen-Kragh J. Six years' experience of using the BacT/ALERT system to screen all platelet concentrates, and additional testing of outdated platelet concentrates to estimate the frequency of false-negative results. Vox Sang. 2005;88(2):93-97.

23. Akkok CA, Brinch L, Lauritzsen GF, Solheim BG, Kjeldsen-Kragh J. Clinical effect of buffy-coat vs. apheresis platelet concentrates in patients with severe thrombocytopenia after intensive chemotherapy. Vox Sang. 2007;93(1):42-48.

24. Cid J, Harm SK, Yazer MH. Platelet transfusion - the art and science of compromise. Transfus Med Hemother. 2013;40(3):160-171.

25. Josephson CD, Mullis NC, Van Demark C, Hillyer CD. Significant numbers of apheresis-derived group $\mathrm{O}$ platelet units have "hightiter" anti-A/A,B: implications for transfusion policy. Transfusion. 2004;44(6):805-808.

26. Cooling LL, Downs TA, Butch SH, Davenport RD. Anti-A and anti-B titers in pooled group $\mathrm{O}$ platelets are comparable to apheresis platelets. Transfusion. 2008;48(10):2106-2113.

27. Menis M, Izurieta HS, Anderson SA, et al. Outpatient transfusions and occurrence of serious noninfectious transfusion-related complications among US elderly, 2007-2008: utility of large administrative databases in blood safety research. Transfusion. 2012;52(9):1968-1976.

28. Gulliksson H. Platelet storage media. Vox Sang. 2014;107(3): 205-212.

29. Estcourt L, Stanworth S, Doree C, et al. Prophylactic platelet transfusion for prevention of bleeding in patients with haematological disorders after chemotherapy and stem cell transplantation. Cochrane Database Syst Rev. 2012;5:CD004269.

30. Stanworth SJ, Dyer C, Choo L, et al; TOPPS Study Group. Do all patients with hematologic malignancies and severe thrombocytopenia need prophylactic platelet transfusions? Background, rationale, and design of a clinical trial (trial of platelet prophylaxis) to assess the effectiveness of prophylactic platelet transfusions. Transfus Med Rev. 2010;24(3):163-171.

31. Annen K, Olson JE. Optimizing platelet transfusions. Curr Opin Hematol. 2015;22(6):559-564.

32. Provan D, Stasi R, Newland AC, et al. International consensus report on the investigation and management of primary immune thrombocytopenia. Blood. 2010;115(2):168-186.

33. Kumar A, Mhaskar R, Grossman BJ, et al; AABB Platelet Transfusion Guidelines Panel. Platelet transfusion: a systematic review of the clinical evidence. Transfusion. 2015;55(5):1116-1127; quiz 1115.

34. Estcourt LJ, Stanworth S, Doree C, et al. Comparison of different platelet count thresholds to guide administration of prophylactic platelet transfusion for preventing bleeding in patients with haematological disorders after chemotherapy or stem cell transplantation. Cochrane Database Syst Rev. 2014;(3):CD010983.

35. Wandt H, Schaefer-Eckart K, Frank M, Birkmann J, Wilhelm M. A therapeutic platelet transfusion strategy is safe and feasible in patients after autologous peripheral blood stem cell transplantation. Bone Marrow Transplant. 2006;37(4):387-392.

36. Kreuger AL, Middelburg RA, Zwaginga JJ, van der Bom JG, Kerkhoffs J-LH. Clinical practice of platelet transfusions in haematooncology. Vox Sang. 2015;109(1):91-94. 
37. Slichter SJ, Kaufman RM, Assmann SF, et al. Dose of prophylactic platelet transfusions and prevention of hemorrhage. $N$ Engl J Med. 2010;362(7):600-613.

38. Heddle NM, Cook RJ, Tinmouth A, et al; SToP Study Investigators of the BEST Collaborative. A randomized controlled trial comparing standard- and low-dose strategies for transfusion of platelets (SToP) to patients with thrombocytopenia. Blood. 2009;113(7):1564-1573.

39. Petz LD, editor. Clinical Practice of Transfusion Medicine. 3rd ed. New York: Churchill Livingstone; 1996.

40. British Committee for Standards in Haematology, Blood Transfusion Task Force. Guidelines for the use of platelet transfusions. Br J Haematol. 2003;122(1):10-23.

41. van der Meer PF, Tomson B, Brand A. In vivo tracking of transfused platelets for recovery and survival studies: an appraisal of labeling methods. Transfus Apher Sci. 2010;42(1):53-61.

42. Vetlesen A, Holme PA, Lyberg T, Kjeldsen-Kragh J. Recovery, survival, and function of transfused platelets and detection of platelet engraftment after allogeneic stem cell transplantation. Transfusion. 2012;52(6):1321-1332.

43. Hussein E. Clinical and quality evaluation of apheresis vs randomdonor platelet concentrates stored for 7 days. Transfus Med. 2015; 25(1):20-26.

44. Slichter SJ, Davis K, Enright H, et al. Factors affecting posttransfusion platelet increments, platelet refractoriness, and platelet transfusion intervals in thrombocytopenic patients. Blood. 2005;105(10):4106-4114.

45. Slichter SJ. Evidence-based platelet transfusion guidelines. Hematology Am Soc Hematol Educ Program. 2007:172-178.

46. Council of Europe. Guide to the Preparation, Use and Quality Assurance of Blood Components. 18th ed. Strasbourg: Council of Europe Publishing; 2014.

47. Yazer MH, Podlosky L, Clarke G, Nahirniak SM. The effect of prestorage WBC reduction on the rates of febrile nonhemolytic transfusion reactions to platelet concentrates and RBC. Transfusion. 2004;44(1):10-15.

48. [No authors listed] Leukocyte reduction and ultraviolet B irradiation of platelets to prevent alloimmunization and refractoriness to platelet transfusions. The Trial to Reduce Alloimmunization to Platelets Study Group. N Engl J Med. 1997;337(26):1861-1869.

49. Pavenski K, Freedman J, Semple JW. HLA alloimmunization against platelet transfusions: pathophysiology, significance, prevention and management. Tissue Antigens. 2012;79(4):237-245.

50. Stroncek DF, Rebulla P. Platelet transfusions. Lancet. 2007;370(9585): 427-438.

51. Ljungman P, Larsson K, Kumlien G, et al. Leukocyte depleted, unscreened blood products give a low risk for CMV infection and disease in CMV seronegative allogeneic stem cell transplant recipients with seronegative stem cell donors. Scand J Infect Dis. 2002;34(5): 347-350.

52. Fast LD. Developments in the prevention of transfusion-associated graft-versus-host disease. Br J Haematol. 2012;158(5):563-568.

53. Dwyre DM, Holland PV. Transfusion-associated graft-versus-host disease. Vox Sang. 2008;95(2):85-93.

54. Mastroianni MA, Llohn AH, Akkok CA, et al. Effect of Mirasol pathogen reduction technology system on in vitro quality of $\mathrm{MCS}+$ apheresis platelets. Transfus Apher Sci. 2013;49(2):285-290.

55. Butler C, Doree C, Estcourt LJ, et al. Pathogen-reduced platelets for the prevention of bleeding. Cochrane Database Syst Rev. 2013;3: CD009072.

56. Schoenfeld H, Spies C, Jakob C. Volume-reduced platelet concentrates. Curr Hematol Rep. 2006;5(1):82-88.

57. Bolton-Maggs PHB, Poles D, Watt A, Thomas D; on behalf of the Serious Hazards of Transfusion (SHOT) Steering Group. In: BoltonMaggs PHB, editor. The 2014 Annual SHOT Report (2015). 2015. Available from: http://www.shotuk.org/wp-content/uploads/report-2014.pdf. Accessed July 2, 2015.

58. Poole J, Daniels G. Blood group antibodies and their significance in transfusion medicine. Transfus Med Rev. 2007;21(1):58-71.
59. Dunstan RA, Simpson MB, Rosse WF. Erythrocyte antigens on human platelets. Absence of Rh, Duffy, Kell, Kidd, and Lutheran antigens. Transfusion. 1984;24(3):243-246.

60. Schmidt M, Spengler H-P, Lambrecht B, Hourfar MK, Seifried E, Tonn T. A new one-platform flow cytometric method for residual cell counting in platelet concentrates. Transfusion. 2009;49(12):2604-2611.

61. Lozano M, Cid J. The clinical implications of platelet transfusions associated with $\mathrm{ABO}$ or Rh(D) incompatibility. Transfus Med Rev. 2003;17(1):57-68

62. Nahirniak S, Slichter SJ, Tanael S, et al; International Collaboration for Transfusion Medicine Guidelines. Guidance on platelet transfusion for patients with hypoproliferative thrombocytopenia. Transfus Med Rev. 2015;29(1):3-13.

63. Cid J, Lozano M, Ziman A, et al; Biomedical Excellence for Safer Transfusion collaborative. Low frequency of anti-D alloimmunization following D+ platelet transfusion: the anti-D Alloimmunization after D-incompatible platelet transfusions (ADAPT) study. Br J Haematol. 2015;168(4):598-603.

64. Bartley AN, Carpenter JB, Berg MP. D+ platelet transfusions in D- patients: cause for concern? Immunohematology. 2009;25(1):5-8.

65. O'Brien TA, Eastlund T, Peters C, et al. Autoimmune haemolytic anaemia complicating haematopoietic cell transplantation in paediatric patients: high incidence and significant mortality in unrelated donor transplants for non-malignant diseases. Br J Haematol. 2004;127(1) $67-75$.

66. Wang M, Wang W, Abeywardane A, et al. Autoimmune hemolytic anemia after allogeneic hematopoietic stem cell transplantation: analysis of 533 adult patients who underwent transplantation at King's College Hospital. Biol Blood Marrow Transplant. 2015;21(1):60-66.

67. Ahrens N, Pruss A, Kahne A, Kiesewetter H, Salama A. Coexistence of autoantibodies and alloantibodies to red blood cells due to blood transfusion. Transfusion. 2007;47(5):813-816.

68. Young PP, Uzieblo A, Trulock E, Lublin DM, Goodnough LT. Autoantibody formation after alloimmunization: are blood transfusions a risk factor for autoimmune hemolytic anemia? Transfusion. 2004;44(1): 67-72.

69. Schmidt M, Geilenkeuser W-J, Sireis W, Seifried E, Hourfar K. Emerging pathogens - how safe is blood? Transfus Med Hemother. 2014;41(1):10-17

70. Bolton-Maggs PHB, Cohen H. Serious hazards of transfusion (SHOT) haemovigilance and progress is improving transfusion safety. $\mathrm{Br} J$ Haematol. 2013;163(3):303-314.

71. Hirayama F. Current understanding of allergic transfusion reactions: incidence, pathogenesis, laboratory tests, prevention and treatment. Br J Haematol. 2013;160(4):434-444.

72. Savage W, Tobian AAR, Ness PM, Kaufman RM. Desensitization in allergic transfusion reactions: evidence from the trial to reduce alloimmunization to platelets. Transfusion. 2014;54(2):496-498.

73. Kiani-Alikhan S, Yong PFK, Grosse-Kreul D, et al. Successful desensitization to immunoglobulin A in a case of transfusion-related anaphylaxis. Transfusion. 2010;50(9):1897-1901.

74. Peters AL, Van Stein D, Vlaar APJ. Antibody-mediated transfusionrelated acute lung injury; from discovery to prevention. Br J Haematol. 2015;170(5):597-614

75. Peters AL, van Hezel ME, Juffermans NP, Vlaar APJ. Pathogenesis of non-antibody mediated transfusion-related acute lung injury from bench to bedside. Blood Rev. 2015;29(1):51-61.

76. Deeg HJ, Spaulding E, Shulman HM. Iron overload, hematopoietic cell transplantation, and graft-versus-host disease. Leuk Lymphoma. 2009;50(10):1566-1572.

77. Watz E, Remberger M, Ringden O, et al. Analysis of donor and recipient $\mathrm{ABO}$ incompatibility and antibody-associated complications after allogeneic stem cell transplantation with reduced-intensity conditioning. Biol Blood Marrow Transplant. 2014;20(2):264-271.

78. Booth GS, Gehrie EA, Bolan CD, Savani BN. Clinical guide to ABOincompatible allogeneic stem cell transplantation. Biol Blood Marrow Transplant. 2013;19(8):1152-1158. 
79. Rowley SD, Donato ML, Bhattacharyya P. Red blood cell-incompatible allogeneic hematopoietic progenitor cell transplantation. Bone Marrow Transplant. 2011;46(9):1167-1185.

80. Pruss A, Kalus U, Radtke H, et al. Universal leukodepletion of blood components results in a significant reduction of febrile non-hemolytic but not allergic transfusion reactions. Transfus Apher Sci. 2004;30(1): 41-46.

81. Laperche S, Worms B, Pillonel J. Blood safety strategies for human T-cell lymphotropic virus in Europe. Vox Sang. 2009;96(2):104-110.

82. Palavecino EL, Yomtovian RA, Jacobs MR. Bacterial contamination of platelets. Transfus Apher Sci. 2010;42(1):71-82.

83. Benjamin RJ, McDonald CP. The international experience of bacterial screen testing of platelet components with an automated microbial detection system: a need for consensus testing and reporting guidelines. Transfus Med Rev. 2014;28(2):61-71.

84. Lieberman L, Maskens C, Cserti-Gazdewich C, et al. A retrospective review of patient factors, transfusion practices, and outcomes in patients with transfusion-associated circulatory overload. Transfus Med Rev. 2013;27(4):206-212.
85. Savage WJ, Tobian AA, Fuller AK, Wood RA, King KE, Ness PM. Allergic transfusion reactions to platelets are associated more with recipient and donor factors than with product attributes. Transfusion. 2011;51(8):1716-1722.

86. Dasararaju R, Marques MB. Adverse effects of transfusion. Cancer Control. 2015;22(1):16-25.

87. Vamvakas EC, Blajchman MA. Transfusion-related mortality: the ongoing risks of allogeneic blood transfusion and the available strategies for their prevention. Blood. 2009;113(15):3406-3417.

88. Helbig G, Stella-Holowiecka B, Wojnar J, et al. Pure red-cell aplasia following major and bi-directional $\mathrm{ABO}$-incompatible allogeneic stemcell transplantation: recovery of donor-derived erythropoiesis after long-term treatment using different therapeutic strategies. Ann Hematol. 2007;86(9):677-683.
International Journal of Clinical Transfusion Medicine

\section{Publish your work in this journal}

International Journal of Clinical Transfusion Medicine is an international, peer-reviewed, open access, online journal publishing clinicalexperimental, policy-making and evidence-based practices of all topics pertaining to clinical transfusion medicine. Original research, short reports, reviews, case reports and commentaries are invited.

\section{Dovepress}

The manuscript management system is completely online and includes a very quick and fair peer-review system, which is all easy to use. Visit http://www.dovepress.com/testimonials.php to read real quotes from published authors. 